\title{
Neuroprotective effect of novel cognitive enhancer noopept on AD-related cellular model involves the attenuation of apoptosis and tau hyperphosphorylation
}

Rita U Ostrovskaya ${ }^{1}$, Yulia V Vakhitova ${ }^{2 *}$, Uliyana Sh Kuzmina², Milyausha Kh Salimgareeva ${ }^{2}$, Liana F Zainullina ${ }^{2}$, Tatiana A Gudasheva', Vener A Vakhitov² and Sergey B Seredenin ${ }^{1}$

\begin{abstract}
Background: Noopept (N-phenyl-acetyl-L-prolylglycine ethyl ester) was constructed as a dipeptide analog of the standard cognition enhancer, piracetam. Our previous experiments have demonstrated the cognition restoring effect of noopept in several animal models of Alzheimer disease (AD). Noopept was also shown to prevent ionic disbalance, excitotoxicity, free radicals and pro-inflammatory cytokines accumulation, and neurotrophine deficit typical for different kinds of brain damages, including AD. In this study, we investigated the neuroprotective action of noopept on cellular model of $A D, A \beta_{25-35}$-induced toxicity in PC12 cells and revealed the underlying mechanisms.

Results: The neuroprotective effect of noopept (added to the medium at $10 \mu \mathrm{M}$ concentration, 72 hours before $A \beta_{25-35}$ ) was studied on $A \beta_{25-35}$-induced injury ( $5 \mu \mathrm{M}$ for $24 \mathrm{~h}$ ) in PC12 cells. The ability of drug to protect the impairments of cell viability, calcium homeostasis, ROS level, mitochondrial function, tau phosphorylation and neurite outgrowth caused by $A \beta_{25-35}$ were evaluated.

Following the exposure of $\mathrm{PC} 12$ cells to $A \beta_{25-35}$ an increase of the level of ROS, intracellular calcium, and tau phosphorylation at Ser396 were observed; these changes were accompanied by a decrease in cell viability and an increase of apoptosis. Noopept treatment before the amyloid-beta exposure improved PC12 cells viability, reduced the number of early and late apoptotic cells, the levels of intracellular reactive oxygen species and calcium and enhanced the mitochondrial membrane potential. In addition, pretreatment of PC12 cell with noopept significantly attenuated tau hyperphosphorylation at Ser396 and ameliorated the alterations of neurite outgrowth evoked by $A \beta_{25-35}$.

Conclusions: Taken together, these data provide evidence that novel cognitive enhancer noopept protects PC12 cell against deleterious actions of A $\beta$ through inhibiting the oxidative damage and calcium overload as well as suppressing the mitochondrial apoptotic pathway. Moreover, neuroprotective properties of noopept likely include its ability to decrease tau phosphorylation and to restore the altered morphology of PC12 cells. Therefore, this nootropic dipeptide is able to positively affect not only common pathogenic pathways but also disease-specific mechanisms underlying Aß-related pathology.
\end{abstract}

Keywords: Alzheimer's disease, Noopept, Beta-amyloid, Tau phosphorylation, Neurites outgrowth

\footnotetext{
* Correspondence: juvv73@gmail.com

${ }^{2}$ Institute of Biochemistry and Genetics Ufa Scientific Centre RAS, Prospect

Oktyabrya, 71, 450054 Ufa, Russia

Full list of author information is available at the end of the article
}

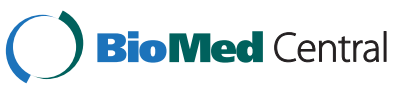

(c) 2014 Ostrovskaya et al.; licensee BioMed Central Ltd. This is an Open Access article distributed under the terms of the Creative Commons Attribution License (http://creativecommons.org/licenses/by/4.0), which permits unrestricted use, distribution, and reproduction in any medium, provided the original work is properly credited. The Creative Commons Public Domain Dedication waiver (http://creativecommons.org/publicdomain/zero/1.0/) applies to the data made available in this article, unless otherwise stated. 


\section{Background}

Alzheimer's disease (AD) is the most common form of neurodegenerative disease, accompanied by age-related dementia, affecting 27 million individuals worldwide [1]. Mechanisms underlying the progression of late-onset $\mathrm{AD}$ consist of a number of interacting events including excessive accumulation of amyloid, aberrant tau-protein phosphorylation, oxidative stress, chronic inflammatory conditions, excitotoxicity, disruption of neurotrophine signaling, impairments in cytoskeleton stability and axonal transport, synaptic and neuronal loss [2]. Pharmacological treatment of AD currently involves cholinesterase inhibitors and NMDA receptor antagonists. Unfortunately, according to most investigators therapeutics of both these groups provide mainly symptomatic benefits without counteracting the progression of the disease [3].

Drug research in the last decade has attempted to develop disease-modifying drugs hopefully able to delay the onset or counteract the progression of $A D$. Strategies targeting at $A \beta$ pathology include decreasing of $A \beta$ production, preventing aggregation of $A \beta$ into amyloid plaques, stimulating clearance of $A \beta$. Neither inhibitors of $\beta$-secretase or $\gamma$-secretase, nor stimulators of $\alpha$-secretase have demonstrated satisfactory potency combined with low toxicity. Drugs targeting tau-protein are known to be divided into several groups: modulators of tau phosphorylation, inhibitors of tau-phosphorylating kinases (e.g. glycogen-synthase-kinase-3 $\beta$, cyclin-dependent kinase-5, p70-S6-kinase) and compounds that prevent tau aggregation and misfolding [4].

$\mathrm{AD}$ is a complex multifactorial pathology, including multiple cycles and subcycles of self-amplifying neurodegenerative process $[5,6]$. Monotherapy targeting single steps in this complicated cascade may explain disappointments in trials with agents affecting only one chain of this "circulus vituosus". So it would be advantageous to explore the possibilities of novel multi-target therapy, aimed to affect different disease-related mechanisms, resulting in additive or synergic therapeutic responses [7].

Neuropeptides have drawn special attention as potential multitarget drugs because of their high biological activity (several orders higher than that of nonpeptide ones), availability of several recognising sites supposed to be complimentary to various targets, the ability to interact with different signal molecules, and minimal side effects. However, their usage as drugs is hindered by the poor bloodbrain barrier penetration and low biological stability [8].

Design of dipeptides is one of the promising approaches taking into account high biological stability of these short molecules and presence of specific ATP-dependent transport systems for di/tripeptides in the intestine (PEPT1) and in the blood-brain barrier (PEPT2) [9]. This provides a basis for brain availability of dipeptides in case of systemic route of administration, including peroral one.
Original approach to the design of active dipeptides is being developed for many years at V.V. Zakusov Institute of Pharmacology. Searching for dipeptides with cognitive enhancing activity Gudasheva et al. based on the idea to get the structures conformationally close to piracetam as a standard cognition enhancer [10]. This drug-based peptide design led us to the series of acyl-prolyl-containing dipeptides possessing pronounced cognitive enhancing and neuroprotective activities [11]. Noopept (N-phenyl-acetylL-prolylglycine ethyl ester, GVS-111, Noopept ${ }^{\circ}$ ) (Figure 1) was chosen from this series because of its pronounced nootropic activity [12], high bioavailability for brain tissues in case of peroral administration [13] and specificity of its mechanism of action [14]. Noopept demonstrated wide spectrum of cognition improving effects [15] as well as pronounced neuroprotective activities both in vivo [15] and in vitro conditions [16]. Compared to piracetam noopept produces a cognition enhancing effect at much lower concentrations and demonstrates activity over a wider range of cognition disturbances and neuronal damages [17]. Noopept showed effectiveness in several animal models of AD: olfactory bulbectomy [18], administration of amyloid into Meinert nucleus [19] and intracerebroventricul administration of diabetogenic toxin streptozotocine [20]. Moreover, the experimental data on cognitive improving effect of noopept have been confirmed in clinic (Phase III and postregistration trials) demonstrating beneficial effect on cognitive functions in patients with MCI of cerebro-vascular or posttraumatic origin [21], and in particular in patients with amnestic form of MCI carrying $A P O E \varepsilon 4^{+}$allele [22]. Taken together these findings prompted us to continue the investigation of noopept on

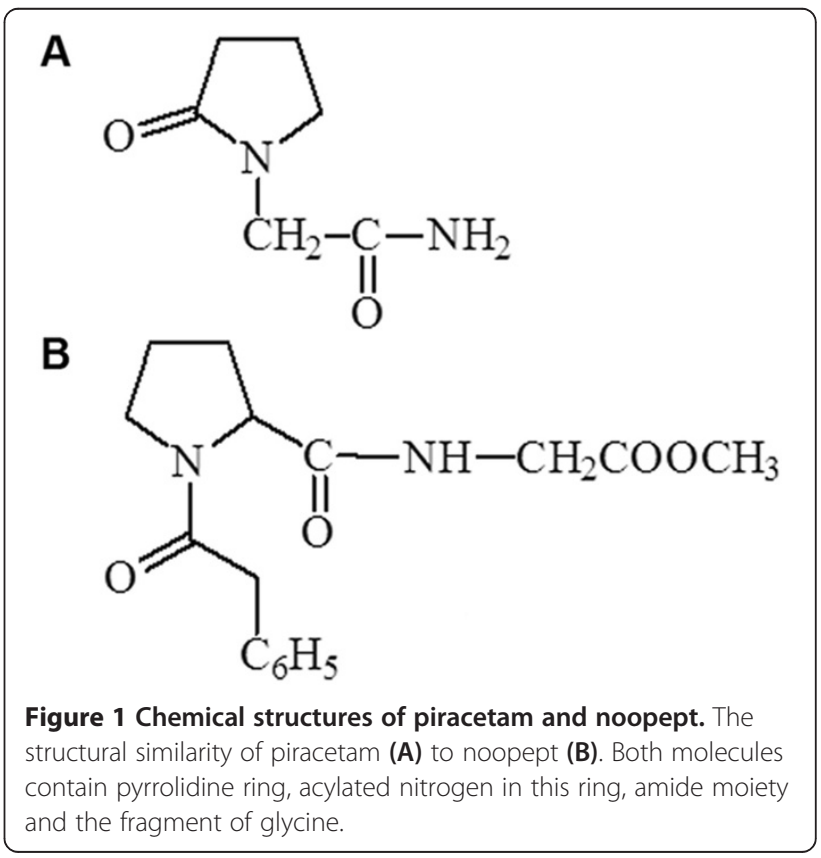


the cellular AD-related model. In the present study we investigated the protective effect of noopept against $\mathrm{A} \beta_{25-35}$-mediated damage of PC12 cells, measuring the cellular viability, apoptosis, intracellular $\mathrm{Ca}^{2+}, \mathrm{ROS}$, mitochondrial membrane potential, tau protein phosphorylation level and neurite outgrowth. $A \beta_{25-35}$ fragment was used as a peptide mimicking several of the toxic effects of the fulllength amyloid- $\beta$ peptide and therefore widely exploiting in both in vitro and in vivo Alzheimer's disease models [23].

\section{Methods}

\section{Cell cultures and treatments}

PC12 cells were cultured routinely at $37^{\circ} \mathrm{C}$ in DMEM medium, supplemented with $10 \%$ fetal bovine serum (FBS), $5 \%$ horse serum, $2 \mathrm{mM}$ L-glutamine, $50 \mu \mathrm{g} / \mathrm{ml}$ gentamicin. To induce PC12 differentiation, NGF $(50 \mathrm{ng} / \mathrm{ml}$; Sigma-Aldrich Inc., USA) was added to the DMEM containing $1 \%$ FBS, followed by a 5-day incubation. Differentiated PC12 (dPC12) cells were pretreated with noopept at concentration of $10 \mu \mathrm{M}$ for $72 \mathrm{~h}$, then cells were rinsed with the medium and exposed to amyloid- $\beta$-peptide $\left(\mathrm{A} \beta_{25-35}, 5 \mu \mathrm{M}\right.$; Tocris Bioscience, UK) for $24 \mathrm{~h}$. Untreated cells were used as control.

\section{Cell viability and apoptosis measurements}

Cell viability was determined by conventional MTT assay. dPC12 cells were plated in 24-well plates with $500 \mu \mathrm{l}$ DMEM medium at the density of $1 \times 10^{4}$ cells/well. After treatment with noopept $(10 \mu \mathrm{M})$ for $72 \mathrm{~h}$ followed by $\mathrm{A} \beta_{25-35}(5 \mu \mathrm{M})$ for $24 \mathrm{~h}$, cells were incubated with $200 \mu \mathrm{l}$ MTT solution $(0.5 \mathrm{mg} / \mathrm{ml})$ at $37^{\circ} \mathrm{C}$ for additional $4 \mathrm{~h}$. Thereafter the cells were solubilized with $200 \mu$ dimethylsulfoxide. After mixing for $10 \mathrm{~min}$ absorbance was measured at $540 \mathrm{~nm}$ using the microplate spectrophotometer (EnSpire ${ }^{\circ}$ Multimode Plate Reader; Perkin Elmer, USA). Cell viability was expressed as the percentage to cell viability in control. Flow cytometry analysis was used to identify the apoptotic cells. dPC12 cells $\left(5 \times 10^{4}\right)$ in 6-well plates were treated as described above. Cells were harvested, washed out with cold phosphate-buffered saline (PBS) and stained with the Annexin V/PI (Annexin V-FITC Kit, Beckman Coulter Inc., USA) according to the manufacturer's instructions. The data were processed using the FCS Express 4 software (De novo Software, USA) and the Cytomics FC 500 flow cytometer (Beckman Coulter, USA).

\section{Measurement of intracellular $\mathrm{Ca}^{2+}$}

After incubation with noopept and $\mathrm{A} \beta_{25-35} \mathrm{dPC} 12$ cells $\left(1 \times 10^{4}\right.$ cells/well $)$ were washed in $\mathrm{Ca}^{2+}$-free HBSS, containing $2.5 \mathrm{mM}$ probenecid (Tocris Bioscience, UK). Then cells were loaded with $4 \mu \mathrm{M}$ of $\mathrm{Ca}^{2+}$ indicator Fluo-4 AM and $0.02 \%$ pluronic acid (Invitrogen, USA) and incubated for $20 \mathrm{~min}$ at $30^{\circ} \mathrm{C}$. Cells were washed out twice in buffer without dye, and incubated for further $15 \mathrm{~min}$. The fluorescence of samples in $0.1 \mathrm{ml}$ of buffer in new 96-well plates was monitored by the microplate spectrophotometer, using $485 \mathrm{~nm}$ excitation filter and $520 \mathrm{~nm}$ emission filter.

\section{Measurement of intracellular reactive oxygen species (ROS)}

The generation of ROS was measured by the oxidative conversion of cell permeable 2,7-dichlorofluorescein diacetate $\left(\mathrm{H}_{2} \mathrm{DCFDA}\right.$; Invitrogen, USA) to fluorescent dichlorofluorescein. dPC12 cells $\left(5 \times 10^{3}\right.$ cells/well $)$ in 96-well plates were cultured for $72 \mathrm{~h}$ in 10\% DMEM medium with noopept at concentrations of $10 \mu \mathrm{M}$. $\mathrm{H}_{2}$ DCFDA was then added directly to the growth medium at a final concentration of $5 \mu \mathrm{M}$; cells were incubated for $1 \mathrm{~h}$ at $37^{\circ} \mathrm{C}$. Cells were rinsed twice with PBS, placed in a fresh medium and treated with $A \beta_{25-35}$ $(5 \mu \mathrm{M})$ for $24 \mathrm{~h}$. After this treatment cells were washed out with PBS. The plates were then read on the microplate spectrophotometer with $485 \mathrm{~nm}$ excitation and $535 \mathrm{~nm}$ emission wavelengths.

\section{Assessment of mitochondrial function}

dPC12 cells were plated at a density of $5 \times 10^{3}$ cells/well in 96-well plates. After treatment with noopept $(10 \mu \mathrm{M})$ for $72 \mathrm{~h}$ and $\mathrm{A} \beta_{25-35}(5 \mu \mathrm{M})$ for $24 \mathrm{~h}$ changes in the mitochondrial membrane potential (MMP) were determined by incubating with $10 \mu \mathrm{M}$ of JC-1 reagent (Invitrogen, USA) for $20 \mathrm{~min}$ at $37^{\circ} \mathrm{C}$ in the darkness. Then the cells were washed with PBS three times, and the fluorescent intensity was determined by microplate reader.

\section{Western blotting}

dPC12 cells $\left(5 \times 10^{4}\right.$ cells/per well $)$ were treated as described above and after incubation the cells were harvested and suspended in lysis buffer $(10 \mathrm{mM}$ Tris, $1 \mathrm{mM}$ EDTA, 1\% SDS, pH 7.5). Protein concentrations were determined by the Bradford assay and equivalent amounts $(10-15 \mu \mathrm{g})$ of total cellular proteins were separated by electrophoresis on a $12 \%$ SDS - polyacrylamide gel. Proteins were transferred to PVDV membrane and probed with anti-p-tau (Ser396; 1:800 v/v; Abcam, England) antibodies. After incubation with horseradish peroxidaseconjugated secondary antibody (1:10000; BioRad, Hercules, USA), immunoblots were developed using "Pierce ECL Western Blotting Substrate" (Thermo Scientific, USA). Membranes were stripped off and reprobed with anti$\beta$-tubulin antibody (1:2000 v/v; Cell Signaling, USA) for loading control. Immunoblots were quantified by densitometry (ImageJ, http://rsbweb.nih.gov/ij/). Data were normalized to $\beta$-tubulin and the corresponding control was taken as $100 \%$. 


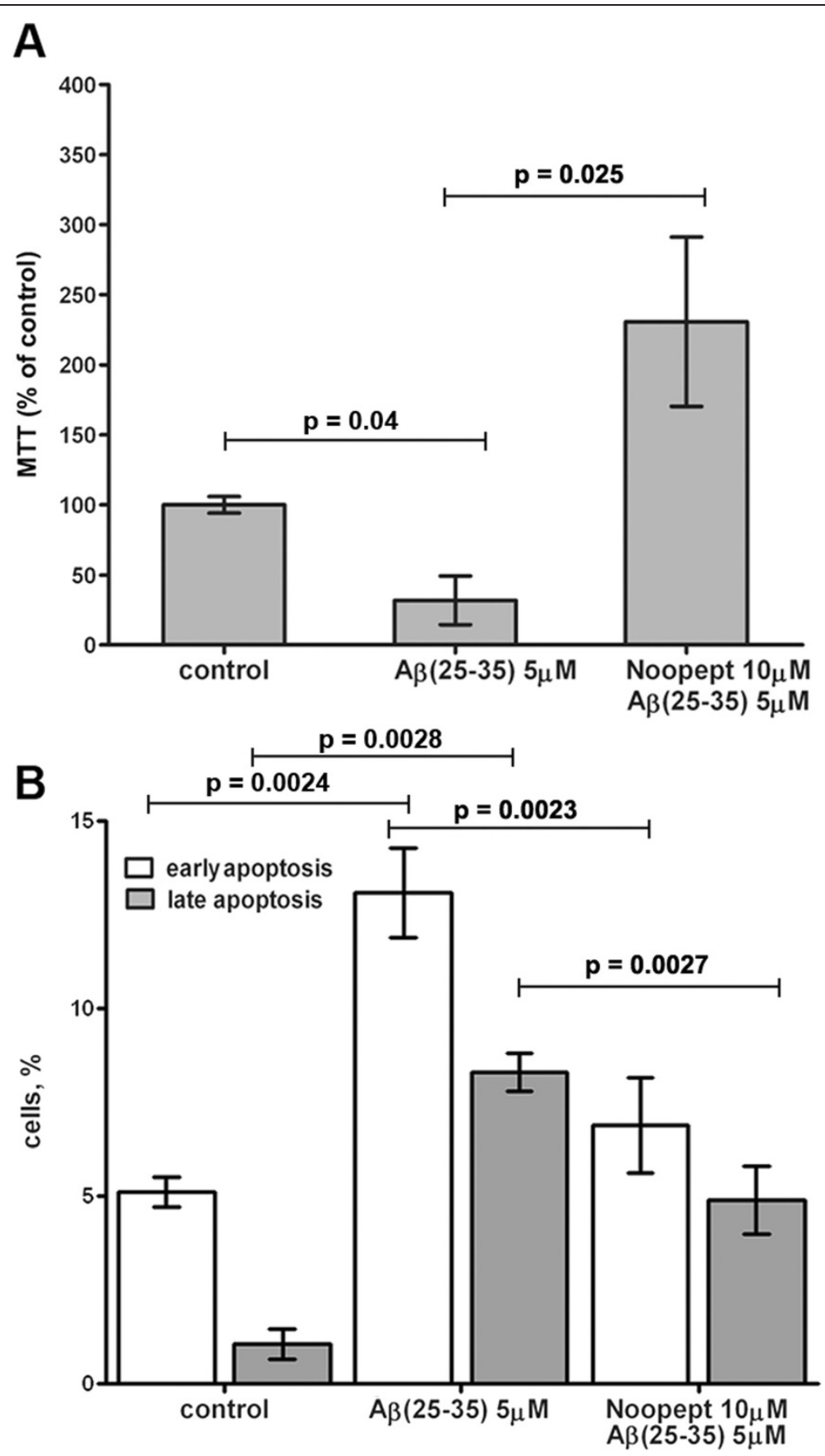

Figure 2 Prevention of $\mathbf{A} \boldsymbol{\beta}_{25-35^{-}}$induced cytotoxicity by noopept. (A) The cells were pre-treated with noopept (10 $\left.\mu \mathrm{M}\right)$ for $72 \mathrm{~h}$ before exposure to $5 \mu \mathrm{M}$ of $A \beta_{25-35}$ for $24 \mathrm{~h}$. Cell viability was determined by MTT assay. Data are expressed as means \pm SEM. Five independent experiments were carried out in triplicate. (B) Apoptosis was assessed by double staining of cells with Annexin-V-FITC and propidium iodide. The bar chart represents the percentage distribution of apoptotic cells. Data are expressed as means \pm SEM. Three independent experiments were carried out in triplicate.

\section{Immunocytochemistry and morphometry}

dPC12 cells $\left(1 \times 10^{4}\right.$ cells/well $)$ were plated onto polyL-lysine coated coverslips in 24-well plates. After the treatment, cells were fixed with $4 \%$ paraformaldehyde, permeabilized with $0.2 \%$ Triton X-100 for 10 min and stained with mouse monoclonal antibody to neuron specific beta III tubulin (1:100; Abcam, England), followed by AlexaFluor 488-conjugated secondary antibody (1:1000; Invitrogen, USA). Coverslips were then incubated with Hoechst $33258(1 \mu \mathrm{g} / \mathrm{ml})$ for $5 \mathrm{~min}$ at room temperature. After washing out with PBS, samples were mounted in Mowiol 4-88 based media (Sigma, USA). 
Fluorescent images were obtained with Axio Imager (Carl Zeiss, Germany) microscope with acquisition settings at the maximal resolution $(1024 \times 1024$ pixels $)$ with $20 x$ objective. Morphological analysis of cells (the number of neurites per cell and average neurite length) was carried out with Sholl analysis (Sholl analysis plug-in for ImageJ, http://rsbweb.nih.gov/ij/). Cells with at least one visible process equal to or greater than one cell body were considered as positive for neurite formation. All neurites of individual PC12 cell were traced, and the number of pixels was automatically converted to micrometers. Comparison of the number of processes between the experimental groups was carried out at a distance of $55 \mu \mathrm{m}$ from the body of the cell. 50 randomly chosen cells were photographed and examined in each of three coverslips for each experimental condition. Results were obtained from three independent experiments.

\section{Statistical analysis}

Each of the above listed parameters was measured in 3 to 5 independent experiments with 3-5 technical replicates per separate experiments. Statistical analysis was performed by one-way analysis of variance (ANOVA) followed by Turkey's post-hoc test (Statistica v.6.0., StatSoft Inc., OK, USA). Data represent the mean \pm SEM. A difference was considered statistically significant if the $p<0.05$.

\section{Results}

\section{Effect of noopept on cell viability and apoptosis in} $A \beta_{25-35}$-treated PC12 cells

A 24-h incubation of PC12 cells with $\mathrm{A} \beta_{25-35}(5 \mu \mathrm{M})$ decreased cell viability measured by MTT-test up to $32 \pm$ 17.35\%. Exposure of PC12 cells to noopept (10 $\mu \mathrm{M}, 72 \mathrm{~h})$ significantly $(\mathrm{p}=0.025)$ reduced cell death caused by $A \beta_{25-35}$, increasing the cell viability to $230 \pm 60.45 \%$ (Figure 2A). Therefore exposure of PC12 cells to noopept
(10 $\mu \mathrm{M}, 72 \mathrm{~h}$ ) not only attenuated the cytotoxic effect of $\mathrm{A} \beta_{25-35}$, but significantly (by about twofold comparing to intact control) increased the cell viability.

Apoptosis was quantified by double staining of cells with Annexin-V/PI (Figure 2B) to distinguish healthy PC12 cells (Annexin V-negative, PI-negative) from early apoptotic cells (Annexin V-positive, PI-negative) and late apoptotic cells (Annexin V-positive, PI-positive). Annexin V/PI staining revealed an increase in the percentage of early and late apoptotic cells from $5.1 \pm 0.4$ and $1.1 \pm 0.4$ in the control group to $13.1 \pm 1.2$ and $8.3 \pm 0.5$ respectively following incubation with $\mathrm{A} \beta_{25-35}$. Pretreatment of PC12 cells with noopept $(10 \mu \mathrm{M}$ for $72 \mathrm{~h})$ prior to $A \beta_{25-35}$ exposure, significantly decreased the percentage of Annexin V +/PI (up to $6.9 \pm 1.3 ; \mathrm{p}=0.0023$ ) and Annexin $\mathrm{V}+/ \mathrm{PI}+$ cells (up to $4.9 \pm 0.9 ; \mathrm{p}=0.0027$ ), thus demonstrating the normalizing drug effect on early as well as on late apoptotic events.

\section{Effect of noopept on $\mathrm{Ca}^{2+}$ level, ROS production and mitochondrial membrane potential}

It is well known that $A \beta_{25-35}$-caused cell death is accompanied by the rise of $\mathrm{Ca}^{2+}$, ROS accumulation and mitochondrial membrane potential disturbance in different neuronal and neuron-like cells. Exposure of differentiated PC12 cells to $A \beta_{25-35}$ resulted in a $25 \%$ elevation of $\left[\mathrm{Ca}^{2+}\right]_{\mathrm{I}}$, while noopept statistically significantly $(p=0.027)$ inhibited calcium rise (Figure 3A). By using of the ROS fluorescent dye $\mathrm{H}_{2}$ DCF-DA we were able to show that $\mathrm{A} \beta_{25-35}$ caused a moderate increase in ROS level, which was abolished by noopept $(\mathrm{p}=0.0024)$ (Figure $3 \mathrm{~B})$. The noopept ability to counteract the $\mathrm{A} \beta_{25-35}$-induced cytotoxicity was also assessed by monitoring of the changes in the mitochondrial membrane potential using fluorescent dye JC-1. When PC12 cells were incubated with $\mathrm{A} \beta_{25-35}$ (5 $\mu \mathrm{M}$ for $24 \mathrm{~h}$ ) a reduction of MMP was detected.
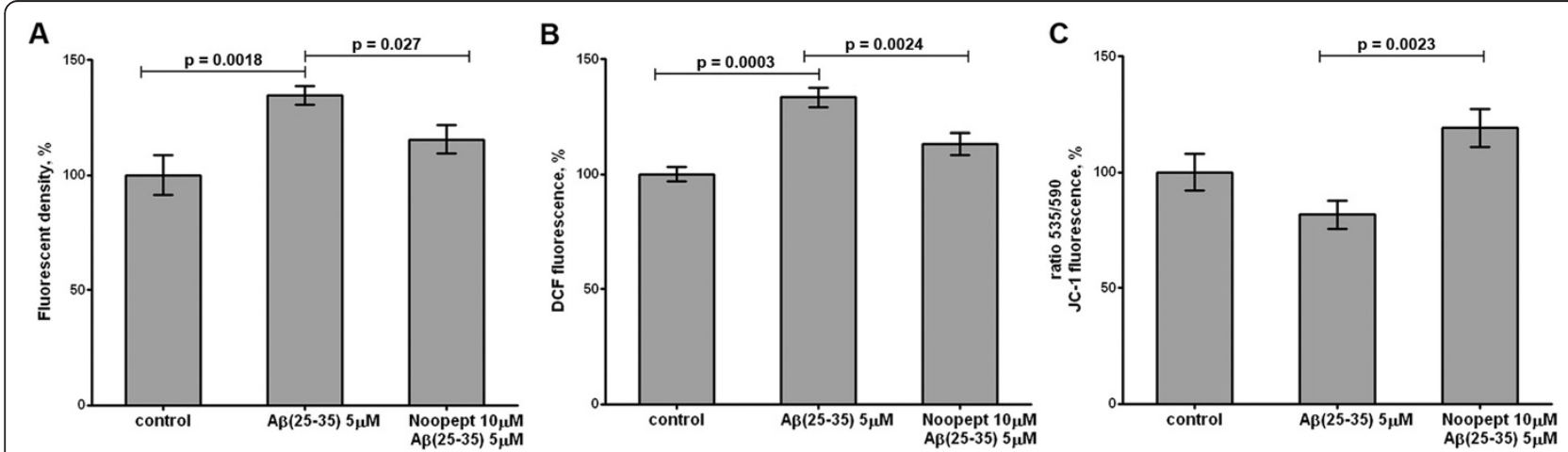

Figure 3 Effect of noopept on $A \beta_{25-35}$-evoked disturbances of intracellular calcium level, ROS accumulation and mitochondrial function.

(A) Pre-treatment with noopept reduces the rate of intracellular calcium in PC12 cells exposed to A $\beta$. (B) Noopept diminishes $A \beta_{25-35}$ - induced enhancement of reactive oxygen species generation. (C) Noopept exposure ameliorates the mitochondrial membrane potential of PC12 cells after $A \beta_{25-35}$-caused stress. Results represent means \pm SEM. The values were obtained from three independent experiments with five technical replicates (A) and from five independent experiments with four technical replicates (B and C). 


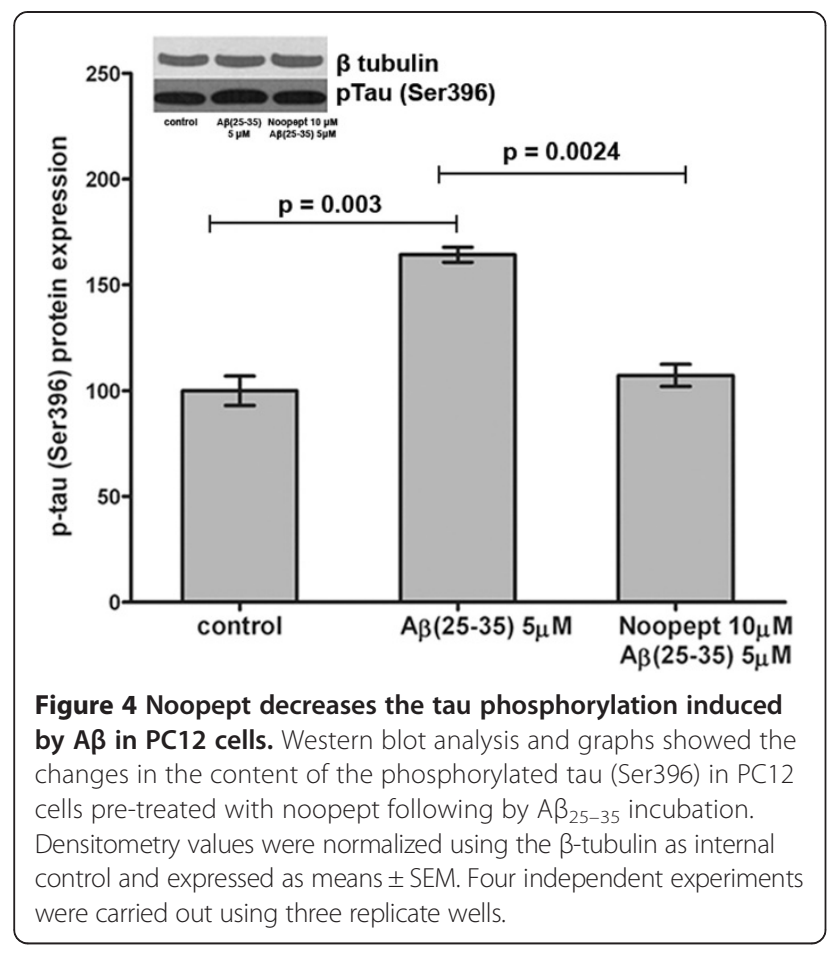

Noopept was shown to protect the mitochondrial membrane potential against $A \beta_{25-35}$ - induced mitochondrial disturbance $(\mathrm{p}=0.0023)$ (Figure $3 \mathrm{C})$. Taken together data obtained suggest that neuroprotective effect of noopept against beta amyloid neurotoxicity involves the limiting of oxidative stress, calcium disregulation and mitochondrial dysfunction.

\section{Noopept decreased tau phosphorylation induced by}

$A \beta_{25-35}$

The effect of $A \beta_{25-35}$ on tau protein phosphorylation level was measured by evaluating of the changes in immunoreactivity using anti-phospho-Ser396-tau antibodies. An increased level of tau phosphorylation at Ser396 was observed in the presence of $5 \mu \mathrm{M} \mathrm{A} \beta_{25-35}$, while the pretreatment with noopept caused the decline of p-tau Ser396 level $(p=0.0024)$ (Figure 4). Thus, the protective effect of noopept on $A \beta_{25-35}$ toxicity apparently involves the attenuation of tau protein phosphorylation.

\section{Noopept ameliorates $A \beta$-induced impairment of PC12 cells morphology}

To further characterize the neuroprotective features of noopept we investigated the effect of the drug on morphology of differentiated PC12 cells. Quantification of neuritic complexity by determination of the average number and length of $\beta$-III-tubulin-immunopositive processes and neurites number at different distances from soma showed that PC12 cell treated with $\mathrm{A} \beta_{25-35}$ exhibited unfavorable changes in their cytoarchitecture. These changes were manifested in decreased number of neurites per cell (2.3 in control cultures versus 1.6 in $A \beta$-exposed cells), significantly reduced neurite length (from $302 \mu \mathrm{M}$ up to $129 \mu \mathrm{M}$ ) (Figure 5A, B) and a decrease of neurites number with increasing distance from soma resulted in simplification of cells. The pretreatment of cells with noopept tended to overcome these detrimental effects of $A \beta$. In particular, the drug restored the number of neurites (2.44 versus $1.64 ; \mathrm{p}=0.0022)$ and increased their length compared to those in $\mathrm{A} \beta$-treated group (from
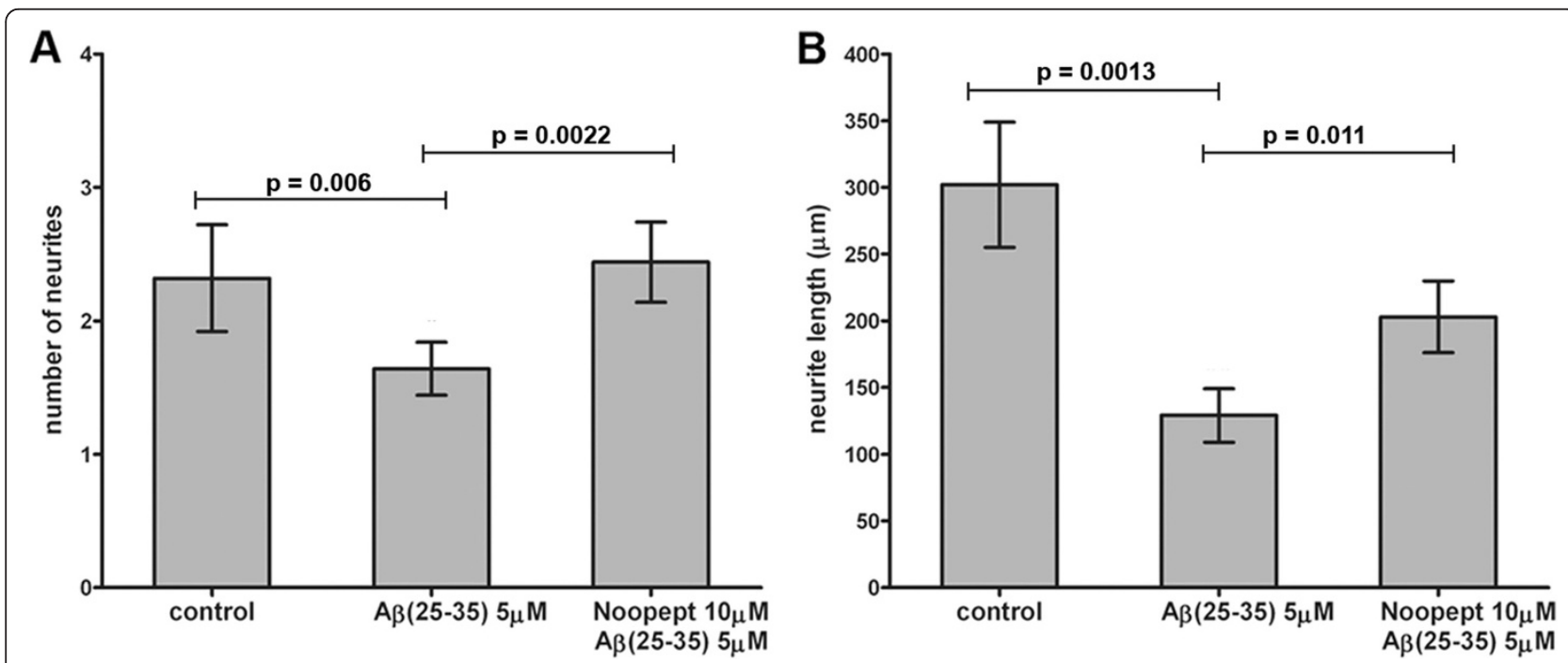

Figure 5 Noopept protects the $A \beta_{25-35}$ - induced impairments of cells morphology. (A) Quantification of number of III $\beta$-tubulin - immunopositive neurites and (B) the average neurites length of PC12 cells after noopept pre-treatment following by $A \beta_{25-35}$ addition. Data expressed as means \pm SEM. Data from three coverslips (50 cells per coverslip) for each experimental group in three independent experiments were evaluated. 
$129 \mu \mathrm{M}$ up to $203 \mu \mathrm{M} ; \mathrm{p}=0.011$ ) (Figure 5A, B). Overall the amount of longer neurites increased in noopept treated cells, compared to cells exposed to $A \beta_{25-35}$ alone.

\section{Discussion}

Present study revealed, for the first time, that the dipeptide cognition enhancing drug noopept protects differentiated PC12 cells against A $\beta$-mediated toxicity as evidenced by enhanced cell viability. While $\mathrm{A} \beta_{25-35}(5 \mu \mathrm{M})$ decreased cell viability, exposure of PC12 cells to noopept has not only overcome the depressing effect of amyloid on cells survival, but even increased it by about twofold compared to intact control. Our results further indicate that pre-treatment of the cells with noopept reduced the percentage of apoptotic cells observed following incubation with the $A \beta_{25-35}$ peptide. Using Annexin V-FITC/PI double staining for the distinction of early- and lateapoptotic cells, we demonstrated that noopept attenuates both early and late apoptotic events induced by $\mathrm{A} \beta$. Our findings of antiapoptotic effect of noopept against $\mathrm{A} \beta$ induced apoptosis are consistent with those obtained with this dipeptide in SH-SY5Y cells underwent to the toxic effect of another misfolded protein, $\alpha$-synuclein amyloids [24].

Numerous in vivo and in vitro studies indicate that beta-amyloid triggers both common to different brain damages pathogenic pathways by inducing the rise of intracellular calcium level, reactive oxygen species production, alteration of mitochondrial function, and $A \beta$-specific signaling pathways resulted in increased tau phosphorylation [25]. Moreover, biochemical disturbances caused by $A \beta$ are accompanied by substantial cytoskeleton abnormalities and consequently impaired axonal transport [26]. Particularly, prominent reductions of neurite outgrowth and neuritic elongation have been observed in different neuronal and neuron-like cells after oligomeric as well as fibrillar $A \beta$ treatment $[27,28]$.

In this study, noopept was found to mitigate the intracellular calcium influx and excessive production of ROS, suggesting that the neuroprotective effects of the drug in this cellular model are probably associated with inhibition of $A \beta$-induced overload of calcium and antioxidant properties. Another mechanism involved in the neuroprotective action of noopept likely includes its ability to ameliorate mitochondrial dysfunction following $\mathrm{A} \beta_{25-35}$ exposure thereby interfering with mitochondrial apoptotic pathway.

These data are in accordance with our previous findings reporting neuroprotective action of noopept in various in vivo and in vitro studies. Noopept was shown to be able to normalize main secondary events by blocking the voltage dependent calcium channels [29], attenuating the neurotoxic effects of glutamate on granular cerebellar neurons [30], decreasing the glutamate release by cortical neurons [31]. Noopept significantly increased neuronal survival and prevented the accumulation of intracellular free radicals and apoptosis in experiments on cultured Down's syndrome neurons [16]. The drug counteracted also the free radicals accumulation caused by $\alpha$-synuclein on cultured neuroblastoma SH-SY5Y cells [24]. Interestingly, noopept was demonstrated to increase immunoreactivity to $\beta$-amyloid in mice with olfactory bulbectomy, considered as one of $\mathrm{AD}$ animal models [18].

Here we have shown for the first time that noopept can protect cells against $A \beta$-mediated toxicity by attenuating an increased tau phosphorylation at Ser396. Moreover, while A $\beta$-treated cells demonstrated decrease of neurites number and their length, noopept was shown to restore the number of neurites and significantly augment their processes length. It is known that extensively phosphorylated tau protein forms pathologic inclusions containing fibrillar aggregates were found in the brain of patients suffering from certain neurodegenerative disorders associated with dementias [32]. Tau protein is considered as one of the microtubules stabilizing proteins playing important role in facilitation of tubulin assembly into microtubules, thus contributing to the neurite outgrowth and maintenance of normal cellular morphology $[33,34]$. Multiple studies provide evidence that the phosphorylation of tau at distinct serine/threonine residues by different protein kinases affects the ability of tau to promote microtubule polymerisation and stability [35]. Abnormally hyperphosphorylated tau possesses lower affinity for microtubules; it promotes the cytoskeleton rearrangements with consequent impairments of axonal transport and intracellular trafficking [36]. Neurite outgrowth of neuronal cells requires the assembly of tubulin into microtubules. The stability of microtubule network depends, at least in part, on the rate and extent of tau phosphorylation. Particularly, neurite outgrowth of neuronal and neuron-like cells was shown to correlate with the phosphorylation of tau at Ser262, Ser356, Ser396/404; these modifications reduce the ability of tau to bind to microtubules $[37,35]$. A number of studies suggest that $A \beta$ peptides under in vitro conditions can cause the increased phosphorylation of tau protein at different sites, thus provoking microtubules destabilization and cytoskeleton network degeneration [38,26,39-41]. Indeed, exposure of neuronal or neuron-like cells to the $\beta$-amyloid results in pronounced neurite retraction and reduced cell complexity [42-45] concomitant with a significant increase in tau phosphorylation at the Ser 396 whereas other serine/ threonine sites - Ser199, Ser202, Thr205 and Ser404 show no significant alteration $[46,47]$. Results from the present study suggest that abrogation of tau hyperphosphorylation at Ser396 by noopept eventually may play a role in restoration and even improvement of PC12 cell morphology. 
Neurite outgrowth promoting activity of noopept found in this cellular model, probably depends on drug's ability to decrease the level of tau phosphorylation, thus affecting tau binding to microtubules. It should be mentioned that our previous experiments demonstrated noopept' ability to increase the expression of NGF and BDNF in hippocampal and hypothalamic neurons in streptozotocin intracerebroventricularly treated rats known to be an experimental model of sporadic AD [20]. PC12 cells express TrkA and respond to NGF by neurite outgrowth [48]. Findings of present study of noopept ability to exert antiapoptotic effect and to increase number and length of neuritis are in line with our supposition on the NGF involvement in above described effects of noopept on PC12 cells.

Recent studies provided evidence that both types of medicines currently used for AD treatment, NMDA receptor antagonists and AchE inhibitors, affect positively at least some of AD-related mechanisms. For example memantine was shown to inhibit the abnormal hyperphosphorylation of tau [49] and protected the neurons from A $\beta$-induced reduction of neurite outgrowth [50]. AchE inhibitor galantamine decreases the neuronal apoptosis induced by $\mathrm{A} \beta_{25-35}$, as well as membrane potential dissipation, suppressing the activity of caspase-9, caspase-12 and caspase-3 [51]. Results comparable to those obtained for noopept were observed for its conformationally related analog, piracetam. This cognitive enhancer attenuates the $A \beta$-caused alterations of mitochondrial membrane potential of $\mathrm{PC} 12$ cells and inhibited the negative effect of $A \beta$ on neurite outgrowth [52].

Taken together findings obtained in this study suggest that noopept affects positively the core pathogenic mechanisms underlying the $A \beta$-mediated toxicity and provide new insights into the neuroprotective action of this drug and its possible beneficial effect in amyloid-related pathology. Further studies to confirm the neuroprotective effect of noopept against $A \beta$-induced neurotoxicity in $A D$ animal model need to be conducted.

\section{Conclusions}

Cognitive enhancer noopept exerts a protective effect against $\mathrm{A} \beta_{25-35}$-induced toxicity in PC12 cells. The protective ability of noopept most likely results from moderate suppression of oxidative stress and intracellular calcium influx, stabilization of mitochondrial function and reducing of apoptosis. Another possible mechanism by which this compound protects cells from amyloid toxicity may be related to the decrease of tau phosphorylation and, eventually, neurite stabilization and outgrowth.

\section{Abbreviations}

Aß: $\beta$-Amyloid; AchE: Acetylcholinesterase E; AD: Alzheimer disease; APOE: Apolipoprotein E; APP: Amyloid precursor protein; BDNF: Brain-derived neurotrophic factor; DMEM: Dulbecco's modified Eagle's medium; FBS: Fetal bovine serum; FITC: Fluorescein isothiocyanate; HBSS: Hank's Balanced
Salt Solution; $\mathrm{H}_{2}$ DCFDA: 2',7'-dichlorodihydrofluorescein diacetate; JC-1: 5,5',6,6'-tetrachloro-1,1',3,3'-tetraethylbenzimi- dazolylcarbocyanine iodide; MCl: Mild cognitive impairment; MMP: Mitochondrial membrane potential; MTT: 3-(4,5-dimethylthiazol-2-yl)-2,5-diphenyl-tetrazolium bromide; NGF: Nerve growth factor; NMDA: N-methyl-D-aspartate; PBS: Phosphate buffered saline; PEPT1: Peptide transporter 1; PEPT2: Peptide transporter 2 ; ROS: Reactive oxygen species; TrkA: Neurotrophic tyrosine kinase receptor type 1.

\section{Competing interests}

The authors declare that they have no competing interest.

\section{Authors' contributions}

SBS, RUO and TAG conceived the experiments. $\mathrm{W}$ and VAV designed the experiments. USK, MKS, LFZ performed the experiments and analyzed the data. RUO and YW interpret the data and wrote the paper. All authors read and approved the final manuscript.

\section{Acknowledgements}

This work was partially supported by the Grant for the state support of leading scientific schools of the Russian Federation (№ 5923.2014.4 to VAV). We are grateful Prof. Grivennikov I.A. (Institute of Molecular Genetics, Russian Academy of Sciences, Moscow) for provision of rat pheochromocytoma cell line.

\section{Author details}

'Zakusov Institute of Pharmacology RAS, Baltiyskaya 8, 125315 Moscow, Russia. ${ }^{2}$ Institute of Biochemistry and Genetics Ufa Scientific Centre RAS, Prospect Oktyabrya, 71, 450054 Ufa, Russia.

Received: 9 April 2014 Accepted: 28 July 2014

Published: 6 August 2014

\section{References}

1. Thies W, Bleiler L: Alzheimer's Association, 2011 Alzheimer's disease facts and figures. Alzheimers Dement 2011, 7:208-244.

2. Krstic D, Knuesel I: Deciphering the mechanism underlying late-onset Alzheimer disease. Nat Rev Neurol 2013, 9(1):25-34.

3. Schneider LS, Dagerman KS, Higgins JP, McShane R: Lack of evidence for the efficacy of memantine in mild Alzheimer Disease. Arch Neurol 2011, 68:991-998.

4. Mangialasche F, Solomon A, Winblad B, Mecocci P, Kivipelto M: Alzheimer's disease: clinical trials and drug development. Lancet Neurol 2010, 9(7):702-716.

5. Longo FM, Massa SM: Neuroprotective strategies in Alzheimer's Disease. NeuroRx 2004, 1:117-127.

6. Buccafusco JJ: Emerging cognitive enhancing drugs. Expert Opin Emerg Drugs 2009, 14:577-589.

7. Frautschy SA, Cole GM: Why pleiotropic interventions are needed for Alzheimer's Disease. Mol Neurobiol 2010, 41:392-409.

8. Kaidanovich O, Eldar-Finkelman H: Peptides targeting protein kinases: strategies implications. Physiology 2006, 21:411-418.

9. Sala-Rabanai M, Loo DDT, Hirayama BA, Turk E, Wright EMJ: Molecular interactions between dipeptides, drugs and the human intenstinal $\mathrm{H}^{+}$oligopeptide cotransporter hPEPT 1. J Physiol 2006, 574:149-166.

10. Gudasheva TA, Voronina TA, Ostrovskaya RU, Rozantsev GG, Vasilevich NI, Trofimov SS, Kravchenko EV, Skoldinov AP, Seredenin SB: Synthesis and antimnestetic activity of a series of $\mathrm{N}$-acylprolyl-containing dipeptides. Eur J Med Chem 1996, 31:151-157.

11. Seredenin SB, Voronina TA, Gudasheva TA, Ostrovskaya RU, Rozantsev GG, Skoldinov AP, Trofimov SS, Halikas J, Garibova TL: Biologically active $\mathrm{N}$-acylprolyldipeptides having antiamnestic, antihypoxic effects. US patent 1995. No. 5.439 .930

12. Ostrovskaya RU, Gudasheva TA, Trofimov SS, Kravchenko EV, Firova FV, Molodavkin GM, Voronina TA, Seredenin SB: GVS-111, an AcylprolylContaining Dipeptide With Nootropic Properties. In Biological Basis of Individual Sensitivity to Psychotropic Drugs. Edited by Seredenin SB, Longo V, Gaviraghi G. UK: Graffhan Press Ltd; 1994:79-91.

13. Boiko SS, Ostrovskaya RU, Zherdev VP, Korotkov SA, Gudasheva TA, Voronina TA, Seredenin SB: Pharmacokinetics of new nootropic acylprolyldipeptide and its 
penetration across the blood-brain barrier after oral administration. Bull Exp Biol Med 2000, 129:359-361.

14. Gudasheva TA, Bojko SS, Voronina TA, Akparov VK, Trofimov SS, Rozantsev GG, Skoldinov AP, Zherdev VP, Seredenin SB: The major metabolite of dipeptide piracetam analogue GVS-111 in rat brain and its similarity to endogenous neuropeptide cyclo-L-prolylglycine. Eur J Drug Metab Pharmacokinet 1997 22:245-252.

15. Ostrovskaya RU, Romanova GA, Barskov IV, Shanina EV, Gudasheva TA, Victorov IV Voronina TA, Seredenin SB: Memory restoring and neuroprotective effects of the proline containing dipeptide, GVS-111, in a photochemical stroke model. Behav Pharmacol 1999, 10:549-553.

16. Pealsman A, Hoyo-Vadillo C, Seredenin SB, Gudasheva TA, Ostrovskaya RU, Busciglio J: GVS-111 prevents oxidative damage and apoptosis in normal and Down's syndrome human cortical neurons. Int J Dev Neurosci 2003, 21:117-124.

17. Ostrovskaia RU, Gudasheva TA, Voronina TA, Seredenin SB: The original novel nootropic and neuroprotective agent Noopept. Eksp Klin Farmakol 2002, 65(5):66-72.

18. Ostrovskaya RU, Gruden MA, Bobkova NA, Sewell RDE, Gudasheva TA Samokhin AN, Seredenin SB, Noppe W, Sherstnev W, Morozova-Roche LA: The nootropic and neuroprotective proline-containing dipeptide Noopept restores spatial memory and increases immunoreactivity to amyloid in an Alzheimer's Disease model. J Psychopharmacol 2007, 21:611-619.

19. Ostrovskaya RU, Belnik AP, Storozheva Zl: Noopept efficiency in experimental Alzheimer Disease (cognitive deficiency caused by beta-amyloid 25-35 injection into Meynert basal nuclei of rats). Bull Exp Biol Med 2008, 146:77-80.

20. Ostrovskaya RU, Tsaplina AP, Vakhitova YV, Salimgareeva MK, Yamidanov RS: Effect of the novel cognition enhancing and neuroprotective dipeptide Noopept on the streptozotocin-induced model of sporadic Alzheimer Disease in rats. Eksp Klin Farmakol 2010, 73:2-6.

21. Neznamov GG, Teleshova ES: Comparative studies of Noopept and piracetam in the treatment of patients with mild cognitive disorders in organic brain diseases of vascular and traumatic origin. Neurosci Behav Physiol 2009, 39(3):311-321.

22. Gavrilova SI, Kolihalov IV, Fedorova JB, Kaljn JB, Selezneva ND: Expirience of Noopept clinical usage in the treatment of mild cognitive impairment syndrome. Modern Therapie of Psychiatric Disorders 2008, 1:27-32.

23. Iversen LL, Mortishire-Smith RJ, Pollack SJ, Shearman MS: The toxicity in vitro of beta-amyloid protein. Biochem J 1995, 311(Pt 1):1-16.

24. Jia X, Gharibyan AL, Öhman A, Liu Y, Olofsson A, Morozova-Roche LA Neuroprotective and nootropic drug Noopept rescues a-synuclein amyloid cytotoxicity. J Mol Biol 2011, 414:699-712.

25. Canevari L, Abramov AY, Duchen MR: Toxicity of amyloid beta peptide: tales of calcium, mitochondria, and oxidative stress. Neurochem Res 2004, 29(3):637-650

26. Henriques AG, Vieira SI, Da Cruz e Silva EF, Da Cruz e Silva OAB: A $\beta$ promotes Alzheimer's disease-like cytoskeleton abnormalities with consequences to APP processing in neurons. J Neurochem 2010, 113:761-771.

27. Spires TL, Hyman BT: Neuronal structure is altered by amyloid plaques. Rev Neurosci 2004, 15(4):267-278.

28. Postuma RB, He W, Nunan J, Beyreuther K, Masters CL, Barrow CJ, Small DH: Substrate-bound beta-amyloid peptides inhibit cell adhesion and neurite outgrowth in primary neuronal cultures. J Neurochem 2000, 74(3):1122-1130.

29. Solntseva El, Bukanova JV, Ostrovskaya RU, Gudasheva TA, Voronina TA, Skrebitsky VG: The effects of piracetam and its novel peptide analogue GVS-111 on neuronal voltage-gated calcium and potassium channels. Gen Pharmacol 1997, 29:85-89.

30. Andreeva NA, Stel'mashuk EV, Isaev NK, Ostrovskaya RU, Gudasheva TA Viktorov IV: Neuroprotective effects of nootropic dipeptide GVS-111 on the model of glucose-oxygen deprivation, glutamate toxicity and oxidative stress in vitro. Bull Exp Biol Med 2000, 130:418-421.

31. Us KS, Klodt PM, Kudrin VS, Sapronova AY, Ostrovskaya RU, Ugryumov MV Rayevsky KS: The effect of the synthetic neuroprotective dipeptide Noopept on glutamate slices. J Neurochem 2007, 1:138-142.

32. Iqbal K, Liu F, Gong CX, Grundke-lqbal I: Tau in Alzheimer disease and related tauopathies. Curr Alzheimer Res 2010, 7(8):656-664.

33. Esmaeli-Azad B, McCarty JH, Feinstein SC: Sense and antisense transfection analysis of tau function: tau influences net microtubule assembly, neurite outgrowth and neuritic stability. J Cell Sci 1994, 107(Pt 4):869-879.
34. Takei Y, Teng J, Harada A, Hirokawa N: Defects in axonal elongation and neuronal migration in mice with disrupted tau and map1b genes. $J$ Cell Biol 2000, 150(5):989-1000

35. Wang JZ, Xia YY, Grundke-lqbal I, lqbal K: Abnormal hyperphosphorylation of tau: sites, regulation, and molecular mechanism of neurofibrillary degeneration. J Alzheimers Dis 2013, 33(Suppl 1):S123-S139.

36. Alonso AC, Zaidi T, Grundke-lqbal I, lqbal K: Role of abnormally phosphorylated tau in the breakdown of microtubules in Alzheimer disease. Proc Natl Acad Sci U S A 1994, 91(12):5562-5566

37. Biernat J, Mandelkow EM: The development of cell processes induced by tau protein requires phosphorylation of serine 262 and 356 in the repeat domain and is inhibited by phosphorylation in the proline-rich domains. Mol Biol Cell 1999, 10(3):727-740.

38. Busciglio J, Lorenzo A, Yeh J, Yankner BA: $\beta$-Amyloid fibrils induce tau phosphorylation and loss of microtubule binding. Neuron 1995, 14:879-888.

39. Avila J, Pérez M, Lim F, Gómez-Ramos A, Hernández F, Lucas JJ: Tau in neurodegenerative diseases: tau phosphorylation and assembly. Neurotox Res 2004, 6(6):477-482.

40. Gendron TF, Petrucelli L: The role of tau in neurodegeneration. Mol Neurodegener 2009, 4:13

41. Zheng WH, Bastianetto S, Mennicken F, Ma W, Kar S: Amyloid beta peptide induces tau phosphorylation and loss of cholinergic neurons in rat primary septal cultures. Neuroscience 2002, 115(1):201-211.

42. Drechsel DN, Hyman AA, Cobb MH, Kirschner MW: Modulation of the dynamic instability of tubulin assembly by the microtubule-associated protein tau. Mol Biol Cell 1992, 3(10):1141-1154.

43. Salinero O, Moreno-Flores MT, Ceballos ML, Wandosell F: beta-Amyloid peptide induced cytoskeletal reorganization in cultured astrocytes. Neurosci Res 1997, 47:216-223.

44. Rapoport M, Dawson HN, Binder LI, Vitek MP, Ferreira A: Tau is essential to beta -amyloid-induced neurotoxicity. Proc Natl Acad Sci U S A 2002, 99(9):6364-6369.

45. Jin M, Shepardson N, Yang T, Chen G, Walsh D, Selkoe DJ: Soluble amyloid beta-protein dimers isolated from Alzheimer cortex directly induce Tau hyperphosphorylation and neuritic degeneration. Proc Natl Acad Sci U S A 2011, 108(14):5819-5824

46. Takashima A, Honda T, Yasutake K, Michel G, Murayama O, Murayama M, Ishiguro $\mathrm{K}$, Yamaguchi $\mathrm{H}$ : Activation of tau protein kinase I/glycogen synthase kinase-3beta by amyloid beta peptide (25-35) enhances phosphorylation of tau in hippocampal neurons. Neurosci Res 1998, 31(4):317-323.

47. Johansson $S$, Jämsä $A$, Vasänge $M$, Winblad B, Luthman J, Cowburn RF: Increased tau phosphorylation at the Ser396 epitope after amyloid beta-exposure in organotypic cultures. Neuroreport 2006, 17(9):907-911

48. Shimoke $\mathrm{K}$, Sasaya $\mathrm{H}$, Ikeuchi $\mathrm{T}$ : Analysis of the role of nerve growth factor in promoting cell survival during endoplasmic reticulum stress in PC12 cells. Methods Enzymol 2011, 490:53-70.

49. Li L, Sengupta A, Haque N, Grundke-Igbal I, Igbal K: Memantine inhibits and reverses the Alzheimer type abnormal hyperphosphorylation of tau and associated neurodegeneration. FEBS Lett 2004, 566:261-269.

50. Hu M, Schurdak ME, Puttfarcken PS, El Kouhen R, Gopalakrishnan M, Li J: High content screen microscopy analysis of $A$ beta 1-42-induced neurite outgrowth reduction in rat primary cortical neurons: neuroprotective effects of alpha 7 neuronal nicotinic acetylcholine receptor ligands. Brain Res 2007, 1151:227-235

51. Liu X, Xu K, Yan M, Wang Y, Zheng $X$ : Protective effects of galantamine against Ab-induced PC12 cell apoptosis by preventing mitochondrial dysfunction and endoplasmic reticulum stress. Neurochem Int 2010, 57:588-599.

52. Kurz C, Ungerer I, Lipka U, Kirr S, Schütt T, Eckert A, Leuner K, Müller WE: The metabolic enhancer piracetam ameliorates the impairment of mitochondrial function and neurite outgrowth induced by beta-amyloid peptide. Br J Pharmacol 2010, 160(2):246-257.

doi:10.1186/s12929-014-0074-2

Cite this article as: Ostrovskaya et al:: Neuroprotective effect of novel cognitive enhancer noopept on AD-related cellular model involves the attenuation of apoptosis and tau hyperphosphorylation. Journal of Biomedical Science 2014 21:74 